\title{
SEISMIC RESPONSE OF MULTI-STOREY IRREGULAR BUILDING WITH FLOATING COLUMN
}

\author{
Isha Rohilla ${ }^{1}$, S.M. Gupta ${ }^{2}$, Babita Saini ${ }^{3}$ \\ ${ }^{1}$ Civil Engineering Department, National Institute of Technology, Kurukshetra, Haryana, India \\ ${ }^{2}$ Civil Engineering Department, National Institute of Technology, Kurukshetra, Haryana, India \\ ${ }^{3}$ Civil Engineering Department, National Institute of Technology, Kurukshetra, Haryana, India
}

\begin{abstract}
In recent times, multi-storey buildings in urban cities are required to have column free space due to shortage of space, population and also for aesthetic and functional requirements. For this buildings are provided with floating columns at one or more storey. These floating columns are highly disadvantageous in a building built in seismically active areas. The earthquake forces that are developed at different floor levels in a building need to be carried down along the height to the ground by the shortest path. Deviation or discontinuity in this load transfer path results in poor performance of the building. In this paper, the critical position of floating column in vertically irregular buildings has been discussed for $G+5$ and G+7 RC buildings for zone II and zone $V$. Also the effect of size of beams and columns carrying the load of floating column has been assessed. The response of building such as storey drift, storey displacement and storey shear has been used to evaluate the results obtained using ETABS software.
\end{abstract}

Keywords: Floating column, Irregular building, Response spectrum method

\section{INTRODUCTION}

A structure with floating can be categorized as vertically irregular as it causes irregular distributions of mass, strength and stiffness along the building height [1]. It is defined as a column which ends at its lower level on a beam and does not reach to the foundation level. Floating column provided in a structural system is highly undesirable especially in higher zones like III, IV \& V.

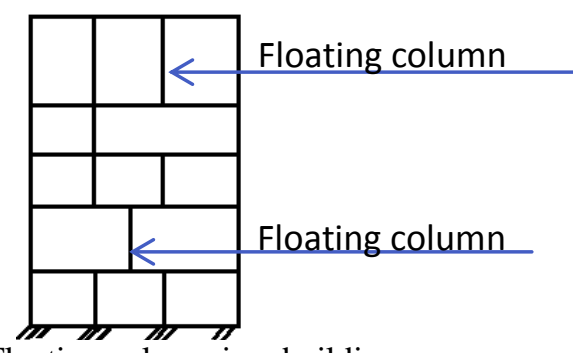

Fig -1: Floating column in a building

In every building the load transfer takes place from horizontal members (beams \& slabs) to vertical members (walls and columns) which transfer the load to foundation level. So there should be a clear load path available for the load to reach the foundation level. Absence of column at any level changes the load path and transfers the floating column load through horizontal beams below it, also known as transfer girders [2]. This altered path will cause large vertical earthquake forces under horizontal earthquake ground motion due to overturning effect [2]. Therefore when floating column is to be necessarily provided special care should be given to the transfer girders and column below the floating column. These beams and column should have sufficient strength to receive the load from floating column and convey it to foundation level. Previous research showed that the floating columns at ground floor have most adverse effect on response of building during earthquake [3]. Ref [4] studied the response of RC frame building with floating column considering different soil conditions. Also magnification factor was determined for safe and economical design of building with floating column. Ref [6] compared the behaviour of structure with floating column of square and rectangular cross section. Through this study, the critical position of floating column in irregular building has been observed. Effect of increase in size of beam and column on response of RC building with floating column during earthquake has also been analysed. Response parameters that have been used in the study are storey drift, storey shear \& storey displacement.

\section{MODELLING DETAILS}

Two irregular RC building models with $\mathrm{G}+5$ \& G+7 storeys have been used for the evaluation. The plan and elevations have been shown in Fig. 2 - Fig. 6. For each model two zones were considered for analysis viz. zone II and zone V. Medium soil conditions were used for analysis. Also for each model 2 cases of irregularities have been taken. Each model consists of two bays at the spacing of $5 \mathrm{~m}$ each and 1 bay at $6 \mathrm{~m}$ spacing in $\mathrm{X}$ direction. However in $\mathrm{Y}$ - direction each bay is at spacing of $5 \mathrm{~m}$. The importance factor and response reduction factor have been used as 1 and 5 respectively in the analysis. Earthquake has been considered in X direction only. Various loads acting on all the models and others parameters are shown in table 1 . 
Table -1: Input parameters

\begin{tabular}{|l|l|l|l|l|}
\hline $\begin{array}{l}\text { Storey } \\
\text { height } \\
(\mathrm{m})\end{array}$ & $\begin{array}{l}\text { Slab } \\
\text { thickness } \\
(\mathrm{mm})\end{array}$ & Dead load & Live load & $\begin{array}{l}\text { Masonry } \\
\text { load }\end{array}$ \\
\hline 3.5 & 100 & $3 \mathrm{kN} / \mathrm{m}^{2}$ & $4 \mathrm{kN} / \mathrm{m}^{2}$ & $16 \mathrm{kN} / \mathrm{m}^{2}$ \\
\hline
\end{tabular}

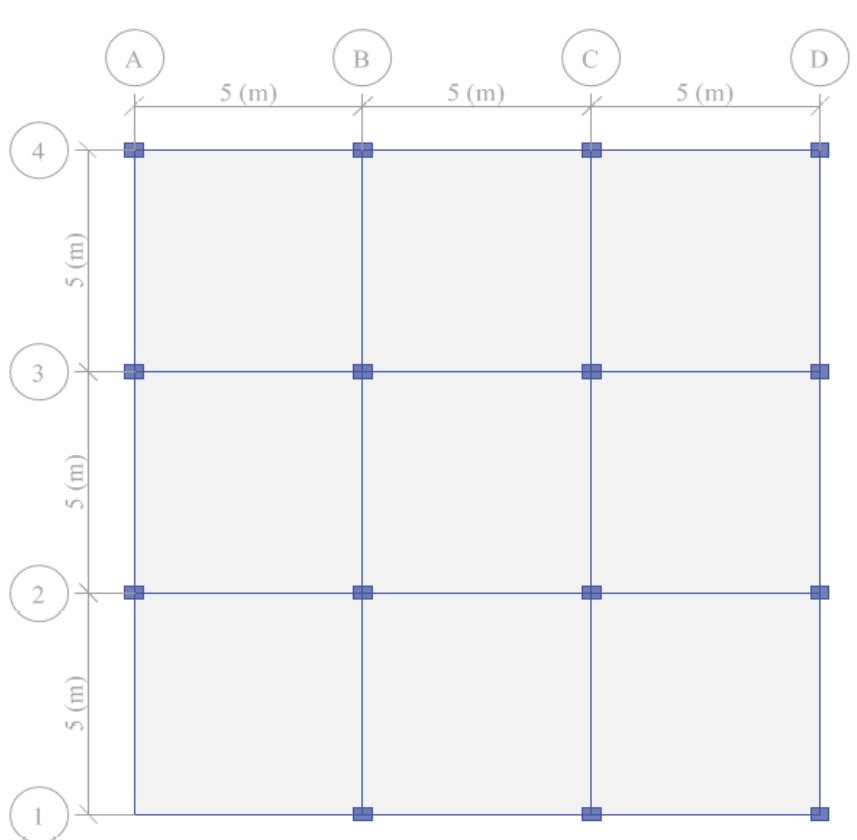

Fig -2: Plan of G+5 \& G+7 RC models

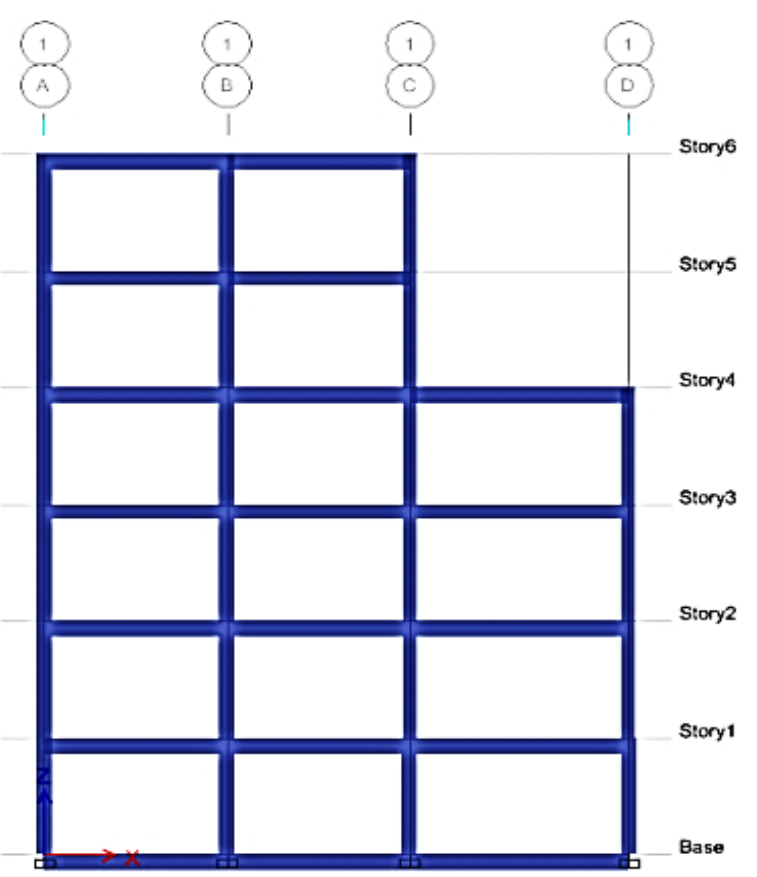

Fig -3: Elevation of G+5 irregular building 1

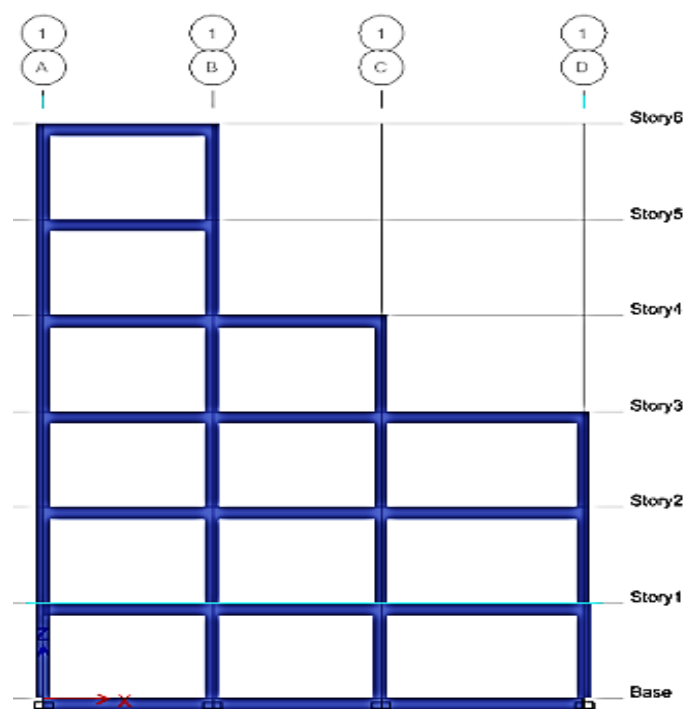

Fig- 4: Elevation of G+5 irregular building 2

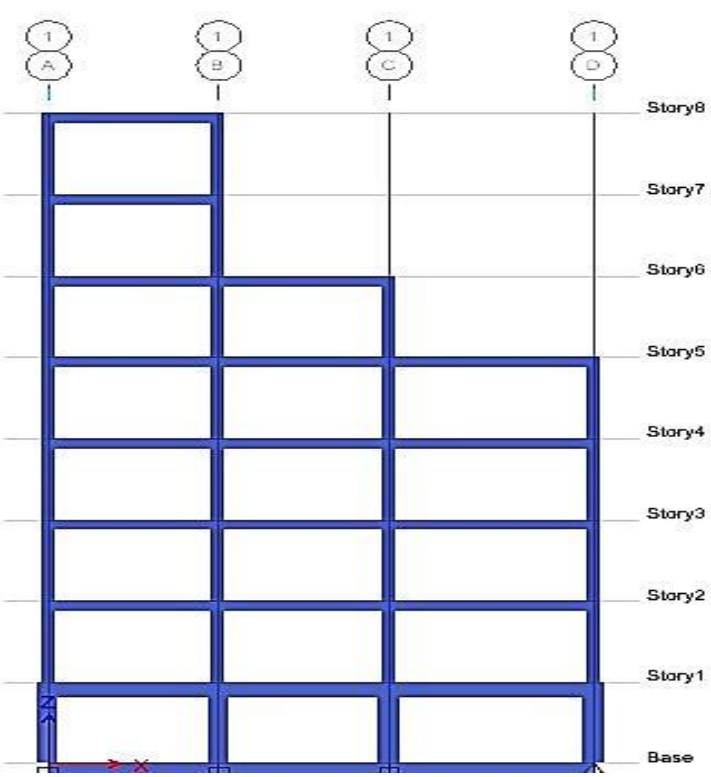

Fig -5: Elevation of G+7 irregular building 1

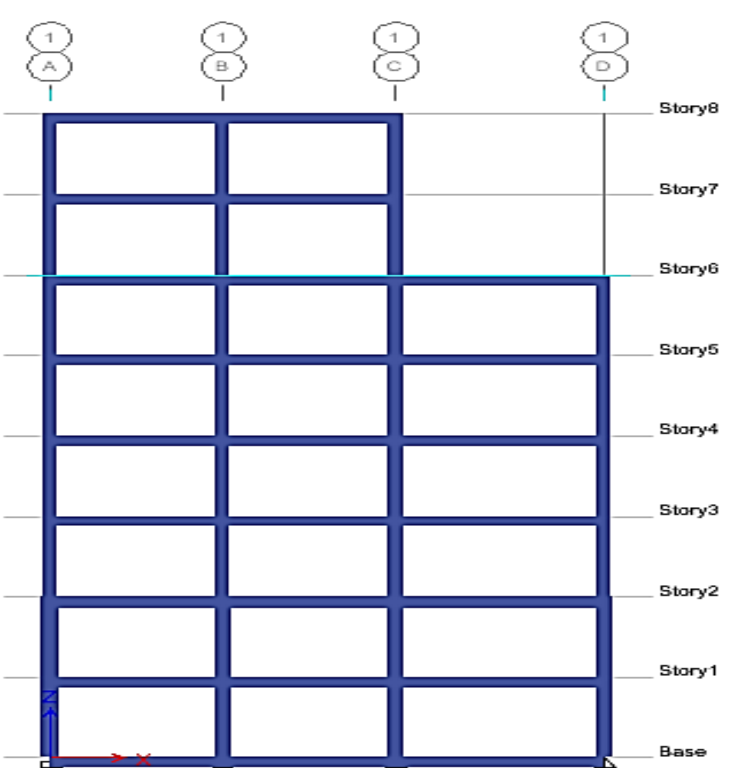

Fig -6: Elevation of $\mathrm{G}+7$ irregular building 2 
For irregular building frame of type 1, three different positions of floating column and for irregular frame of type 2, four positions have been taken. The discontinuity has been provided at the ground floor only because it has already been observed in previous research studies that floating column caused adverse effects when discontinued at ground floor. The positions of floating column for both the building frames have been shown in figure6 (a), (b), (c) \& (d).

For irregular type 1 structures only three positions have been taken (position 1, $2 \& 4$ ). To determine the effect of size of beams and columns supporting floating column (beams \& columns of first floor), three combinations of beams and columns sizes as shown in table 2 have been taken maintaining aspect ratio. The results on storey shear, storey displacement and storey drift have been compared with reference size.

For each size of transfer girder and column supporting floating column, two cases have been taken. In case 1 size of only ground floor beams and column has been changed and in case 2 the size of both first floor and ground floor beams and columns has been changed.

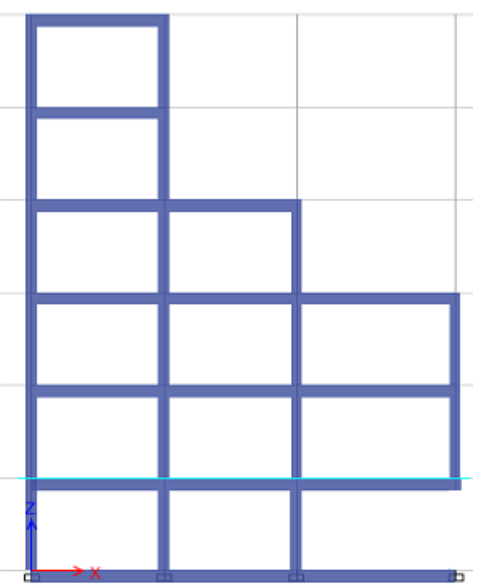

(a):Position 1

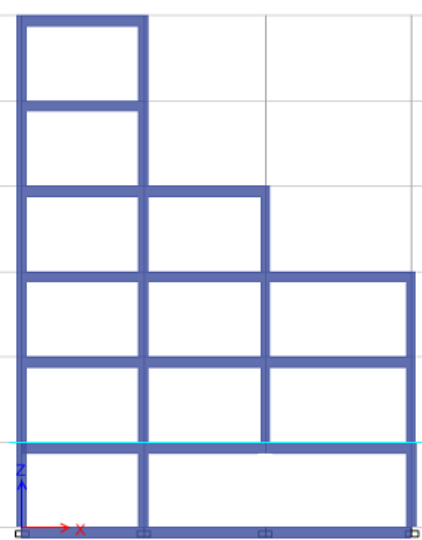

(b):Position 2

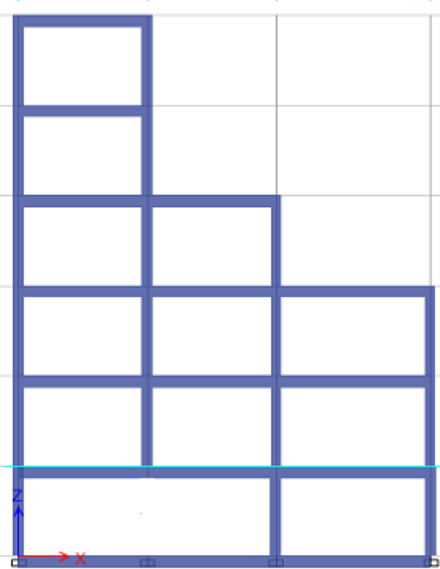

(c): Position 3

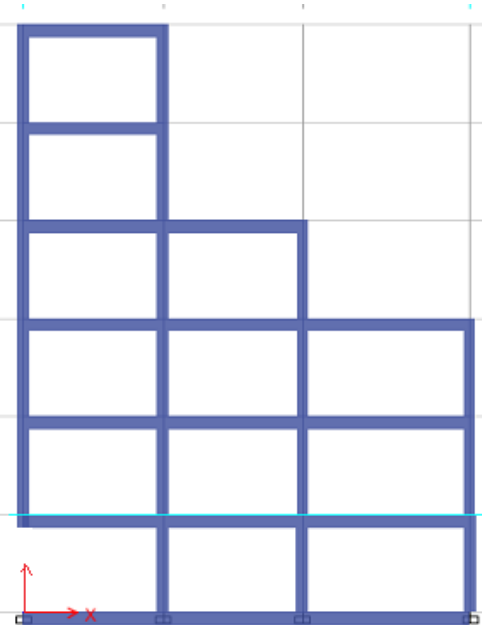

(d): Position 4

Fig -7: Different positions of floating column in irregular building type 2 for both $\mathrm{G}+5$ and $\mathrm{G}+7$ building frames

Table 1: Different sizes of beams and columns

\begin{tabular}{|l|l|l|l|}
\hline $\begin{array}{l}\text { Reference } \\
\text { Beam }\end{array}$ & $250 \times 450$ & $\begin{array}{l}\text { Reference } \\
\text { Column }\end{array}$ & $250 \times 400$ \\
\hline Beam a & $250 \times 500$ & Column a & $250 \times 450$ \\
\hline Beam b & $300 \times 600$ & Column b & $300 \times 500$ \\
\hline Beam c & $300 \times 650$ & Column c & $300 \times 600$ \\
\hline
\end{tabular}

\section{ANALYSIS OF RESULT}

The graphs showing the response parameters in both types of irregular buildings $\mathrm{G}+5$ and $\mathrm{G}+7$ have been shown in fig. 8 - fig. 19. Location of floating column has been varied in order to determine most critical position. Here 'ref' denotes the model with reference beam \& column size without floating column. 


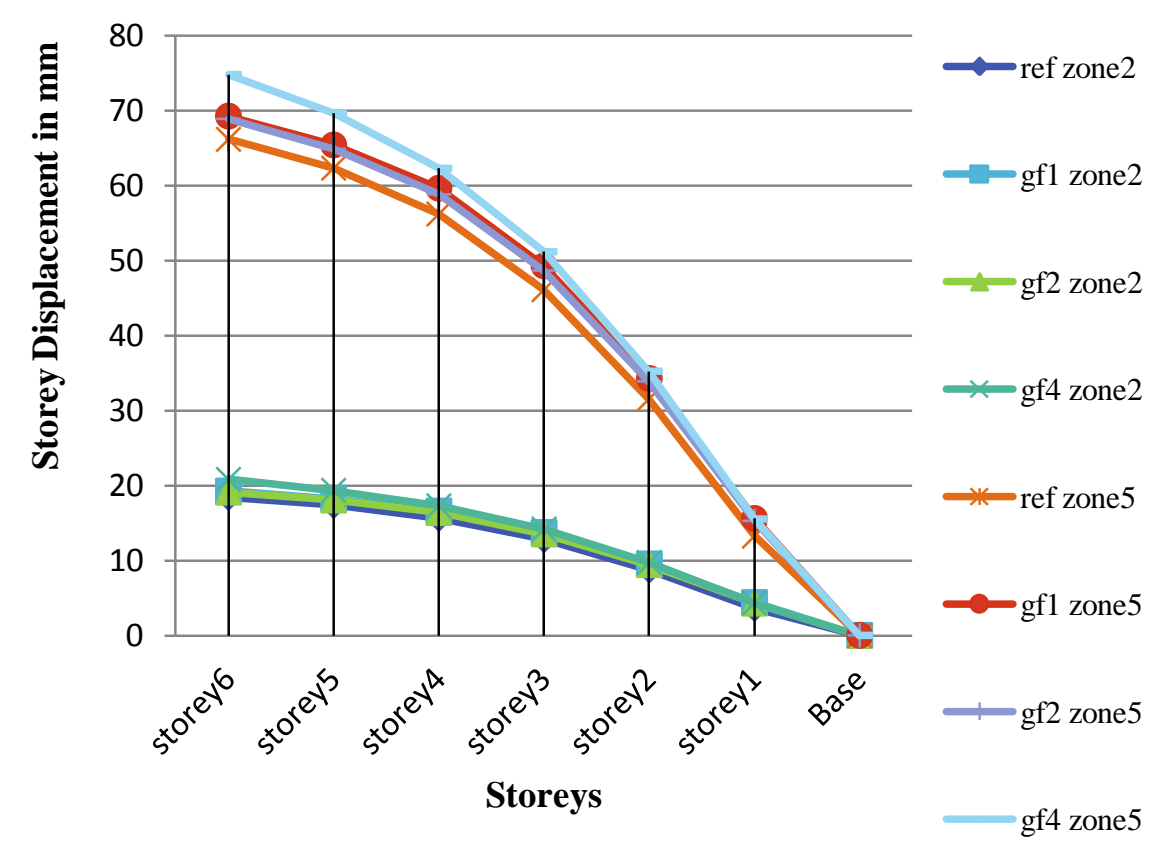

Fig -8: Storey displacement in G+5 irregular building 1

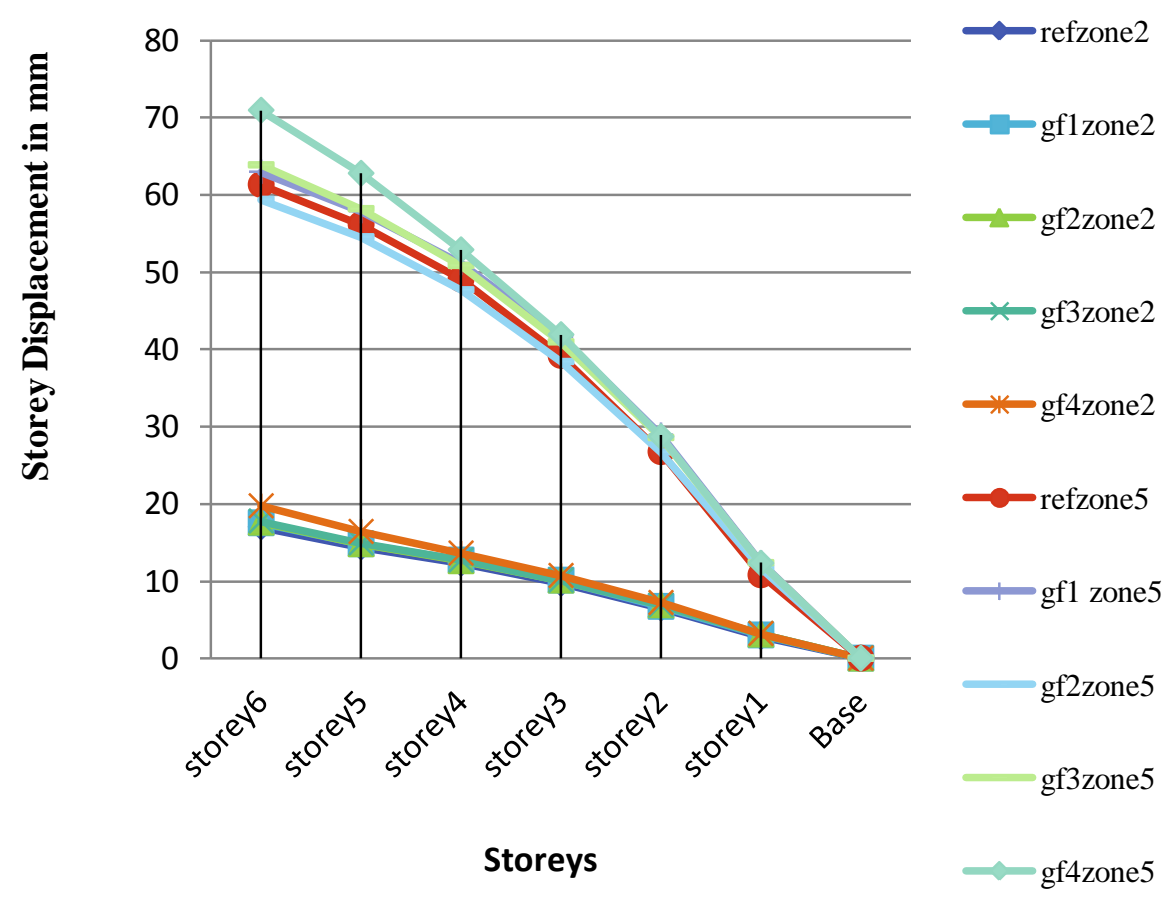

Fig -9: Storey displacement in G+5 irregular building 2 


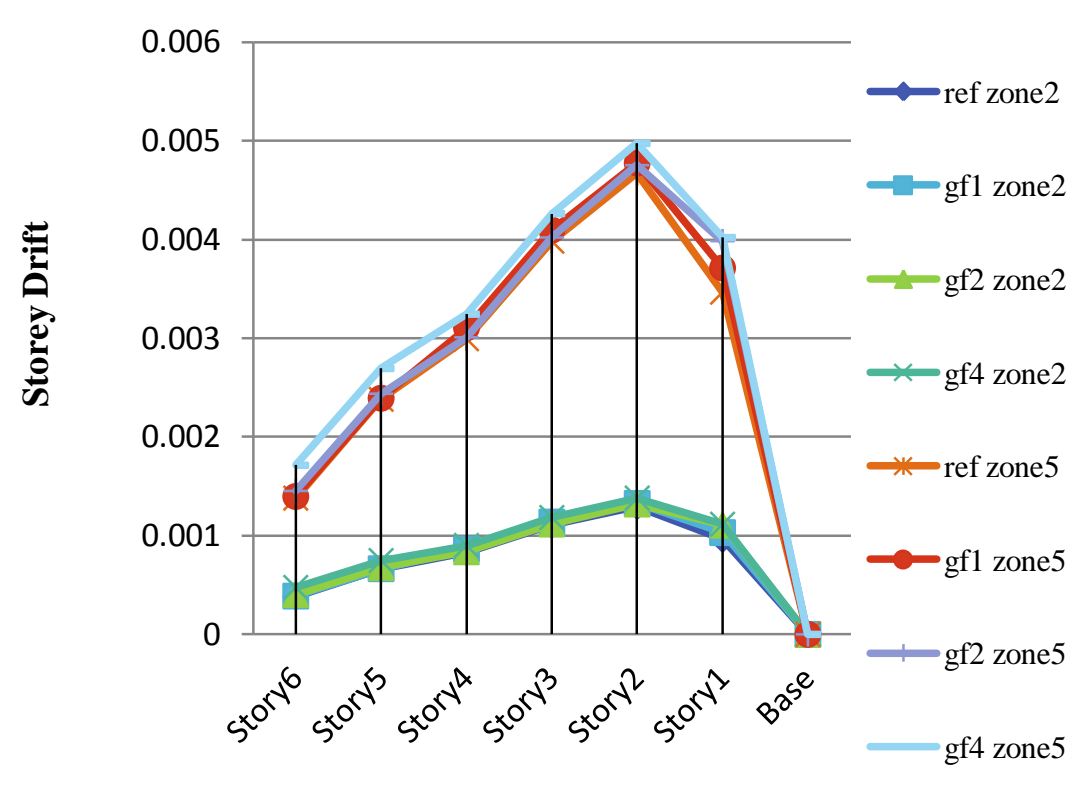

Storeys

Fig -10: Storey drift in G+5 irregular building 1

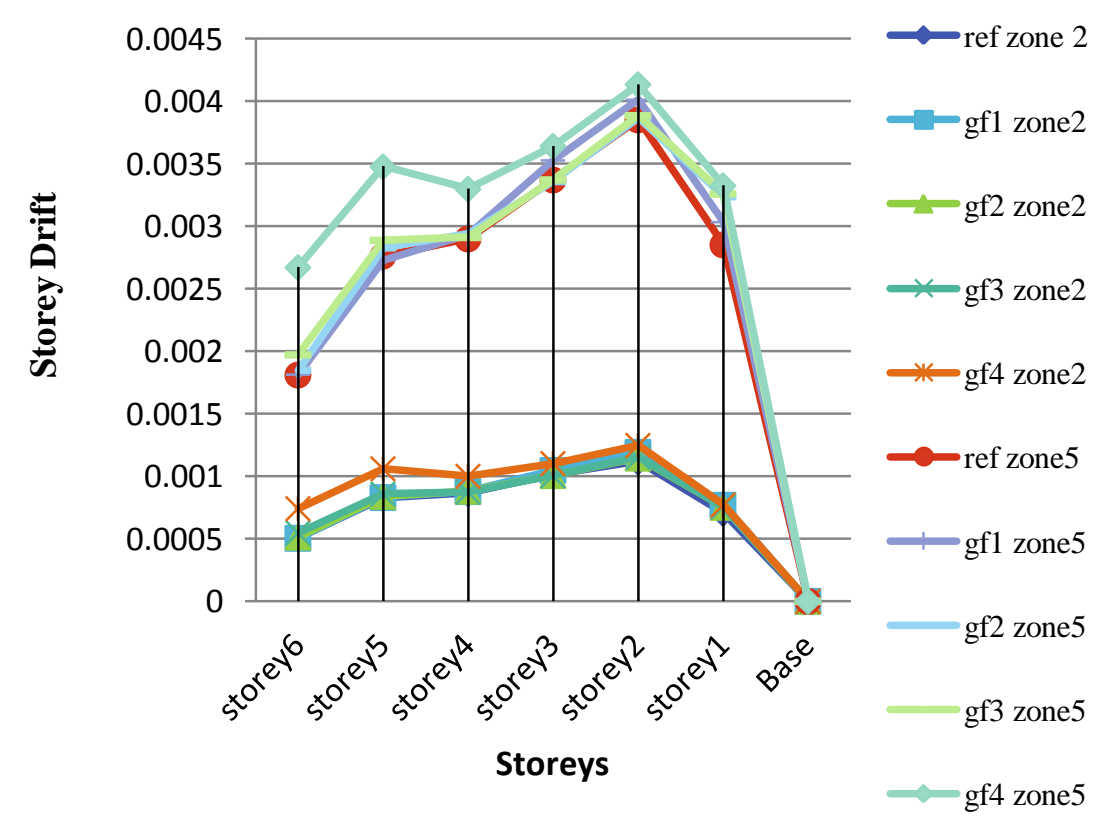

Fig -11: Storey drift in G+5 irregular building 2 


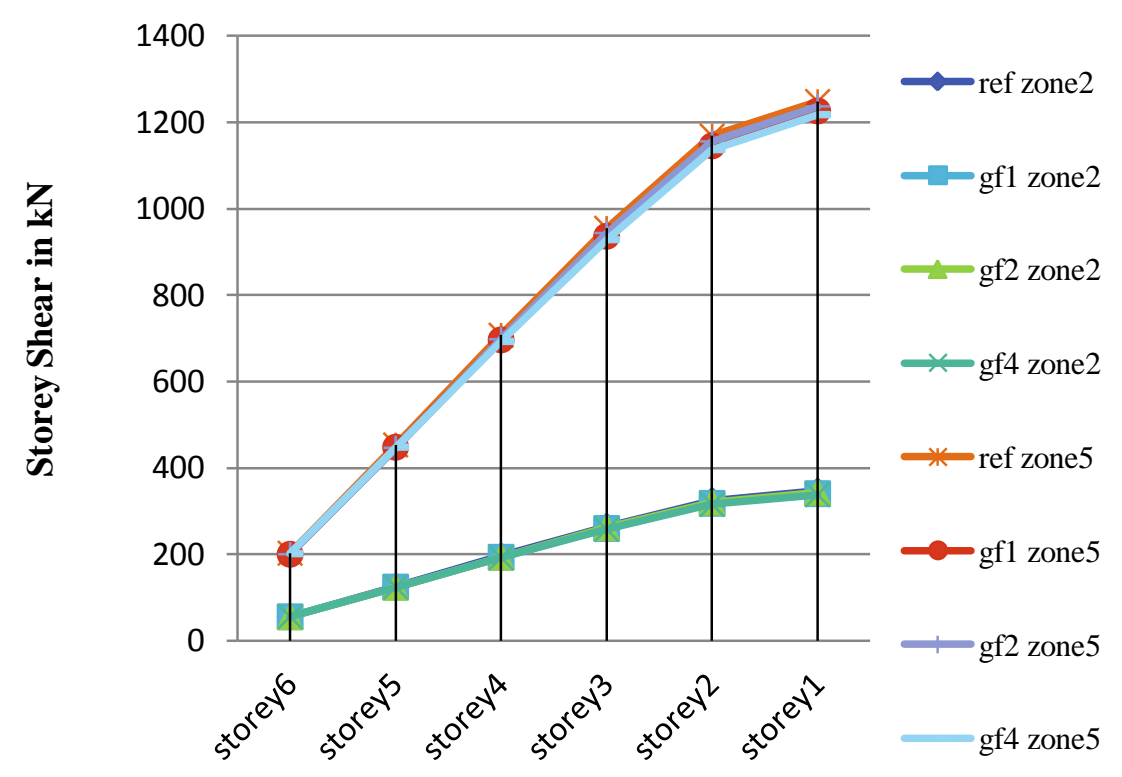

Storeys

Fig -12: Storey shear in G+5 storey irregular building 1

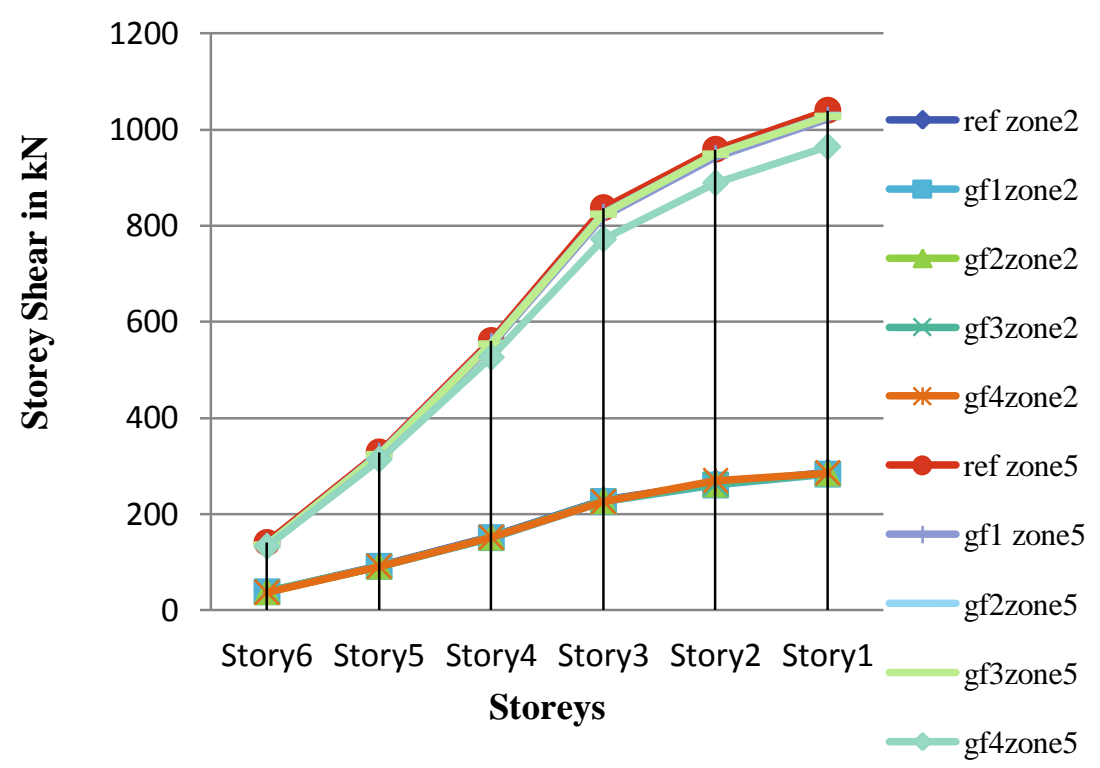

Fig- 13: Storey shear in G+5 irregular building 2 


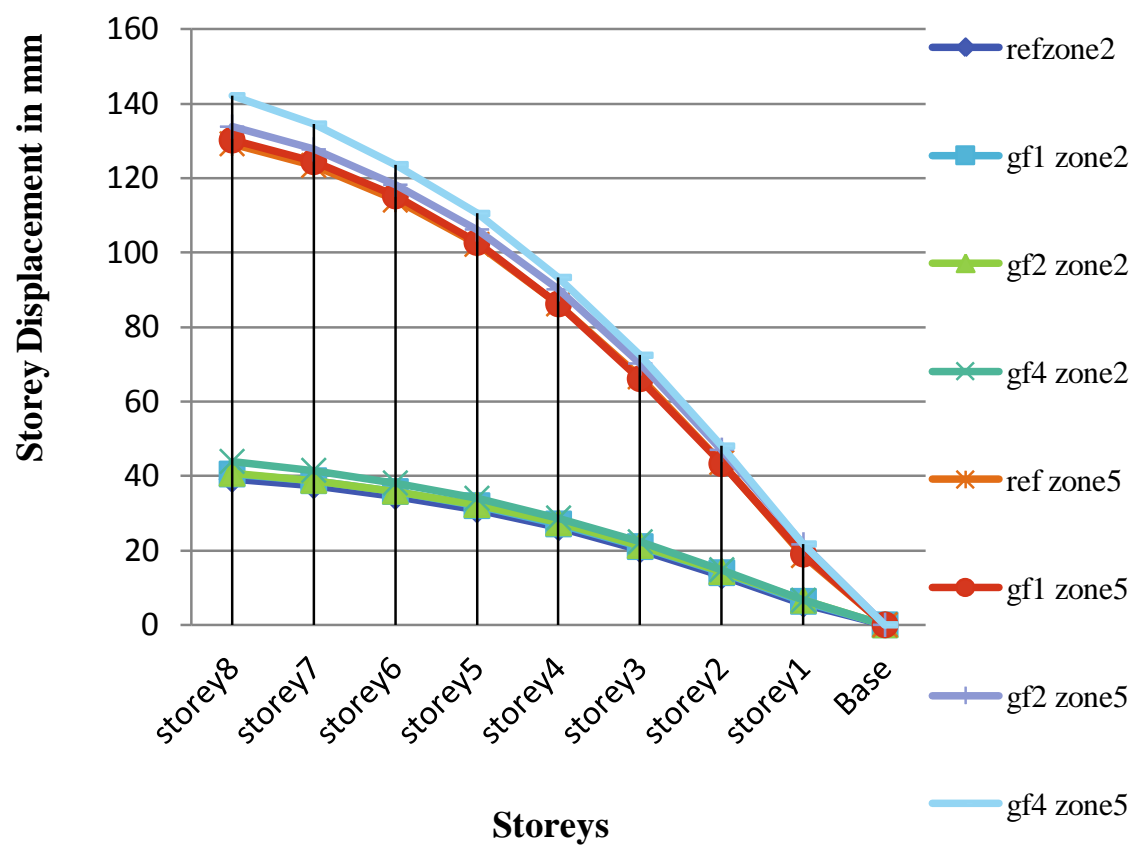

Fig -14: Storey displacement in G+7 irregular building 1

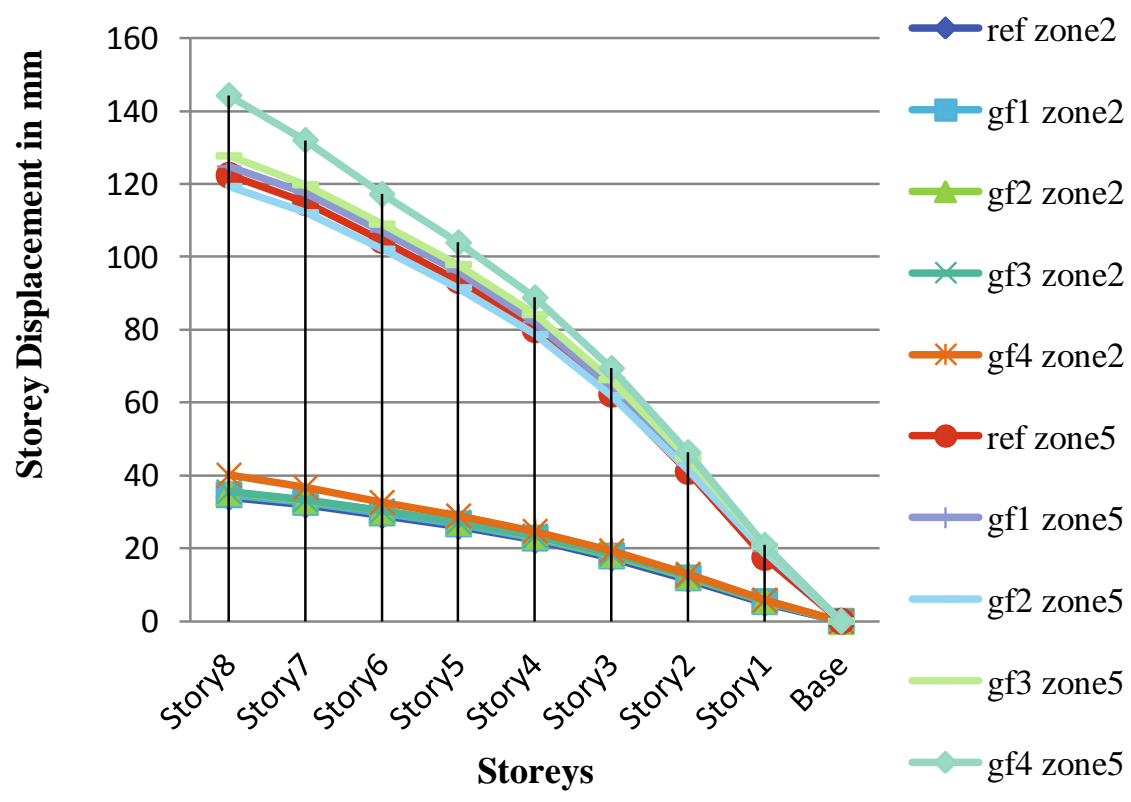

Fig -15: Storey displacement in G+7 irregular building 2 


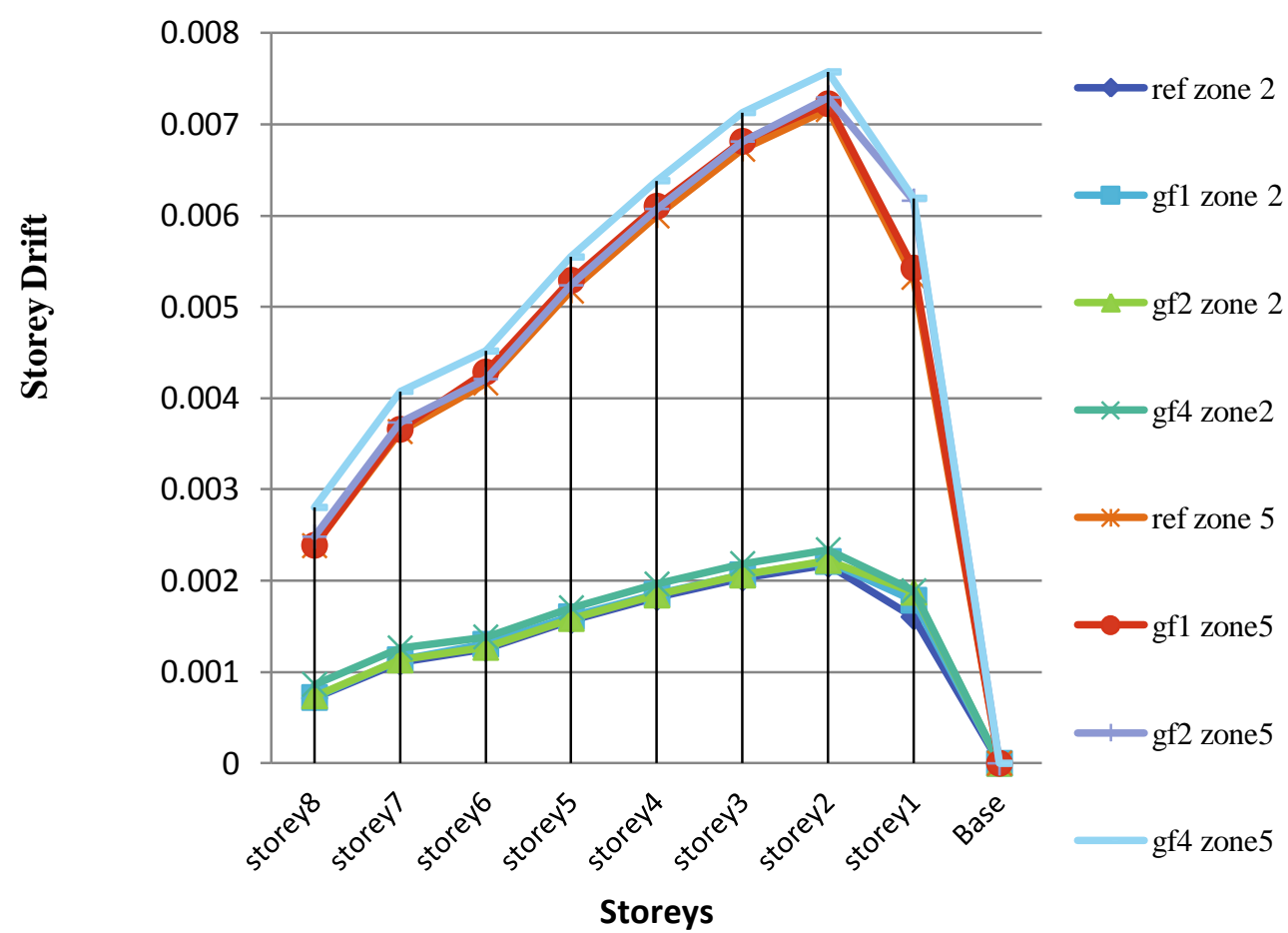

Fig -16: Storey drift in G+7 irregular building 1

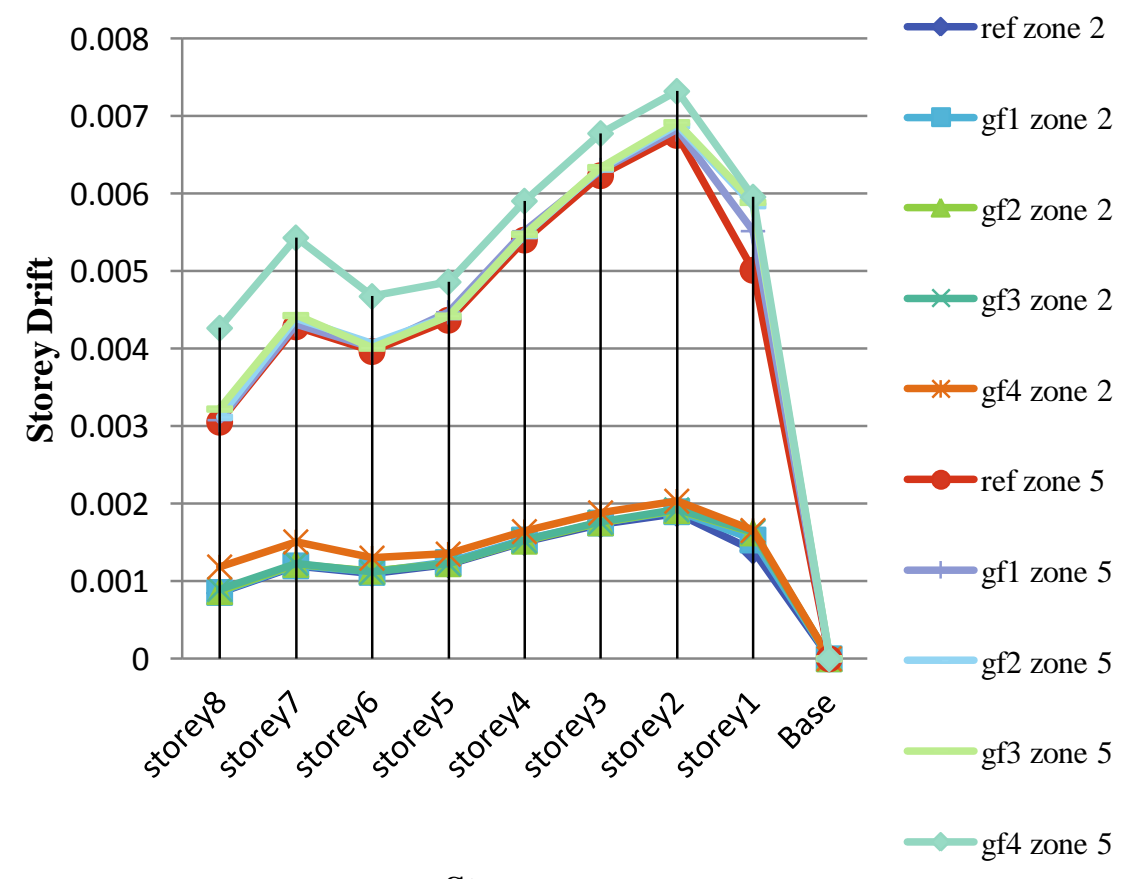

Storeys

Fig -17: Storey drift in G+7 irregular building 2 


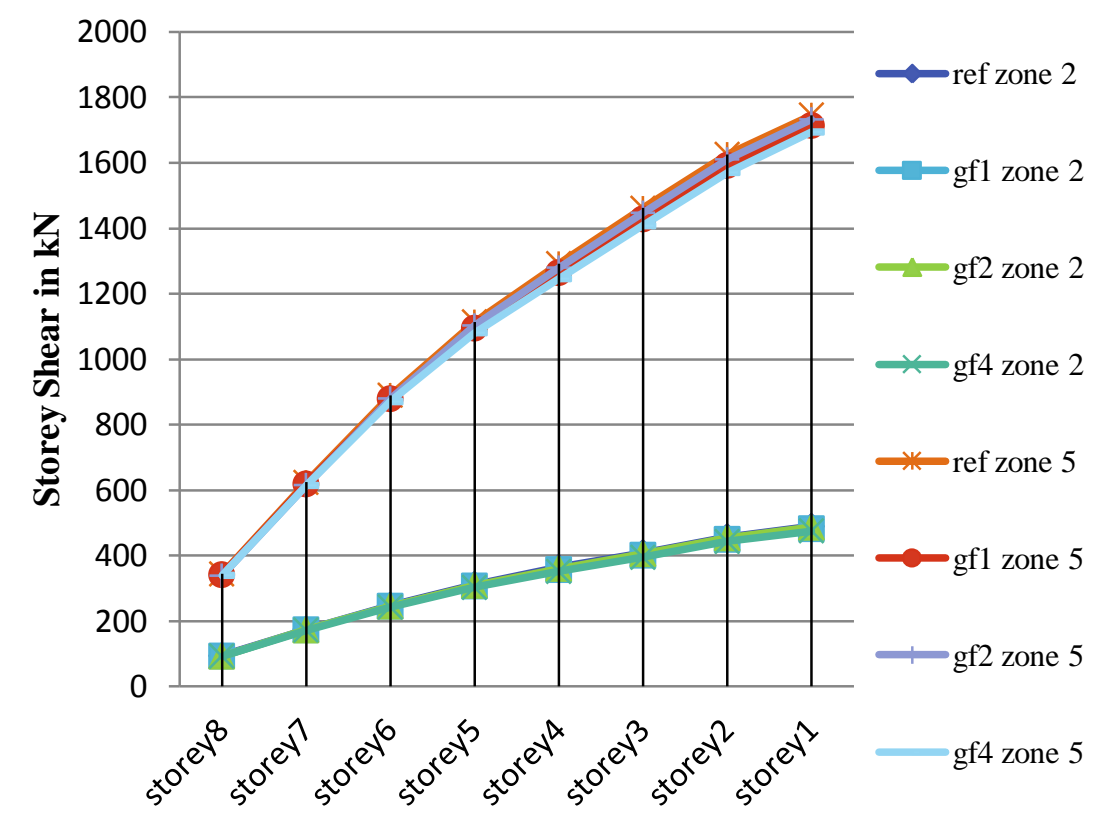

Storeys

Fig -18: storey shear in G+7 irregular building 1

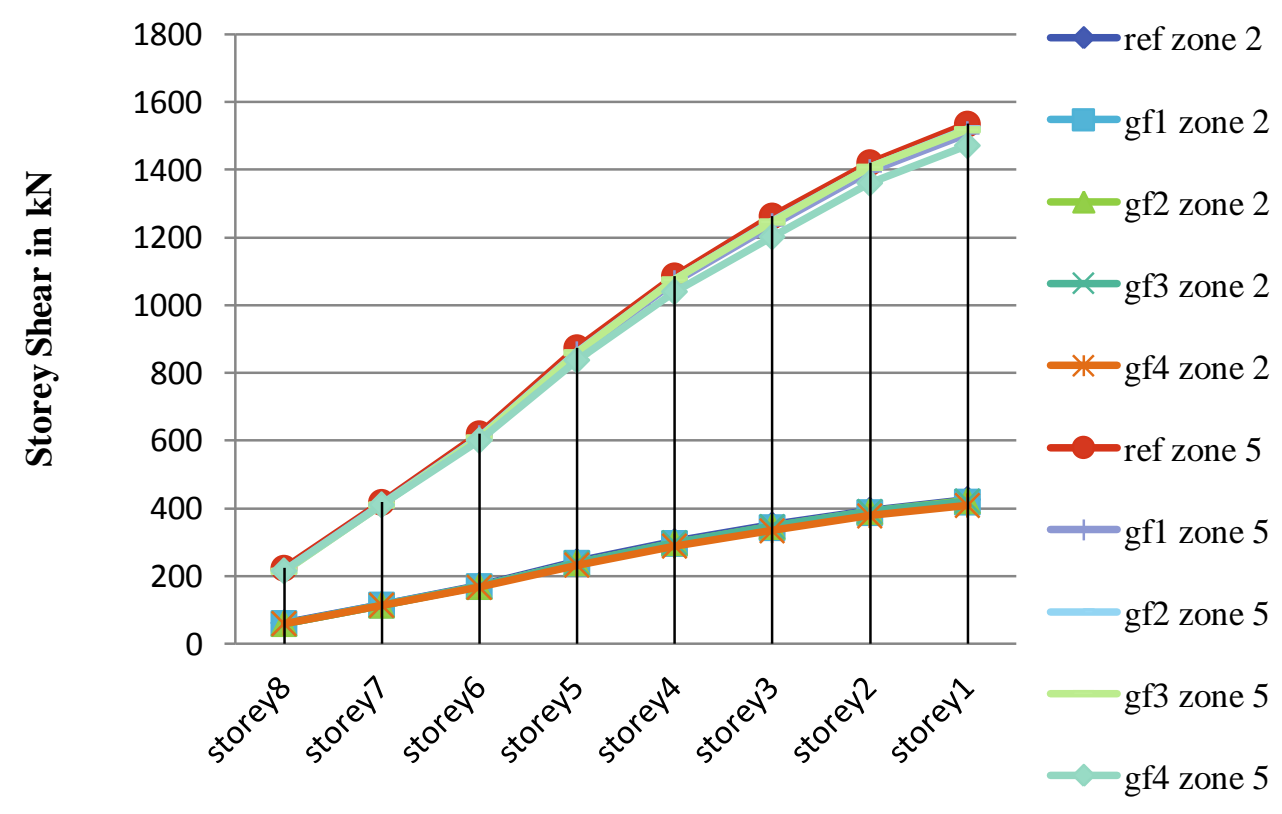

Storeys

Fig -19: Storey shear in G+7 irregular building 2

The changes brought by different sizes of beams and column for both the cases on structural response parameters have been shown in bar charts fig. 20 - fig. 31 for most critical position of floating column (position 4). As the floating column is not causing much effect on response of structures in zone 2 therefore effect of changes on structural response has been shown for zone 5 only. 


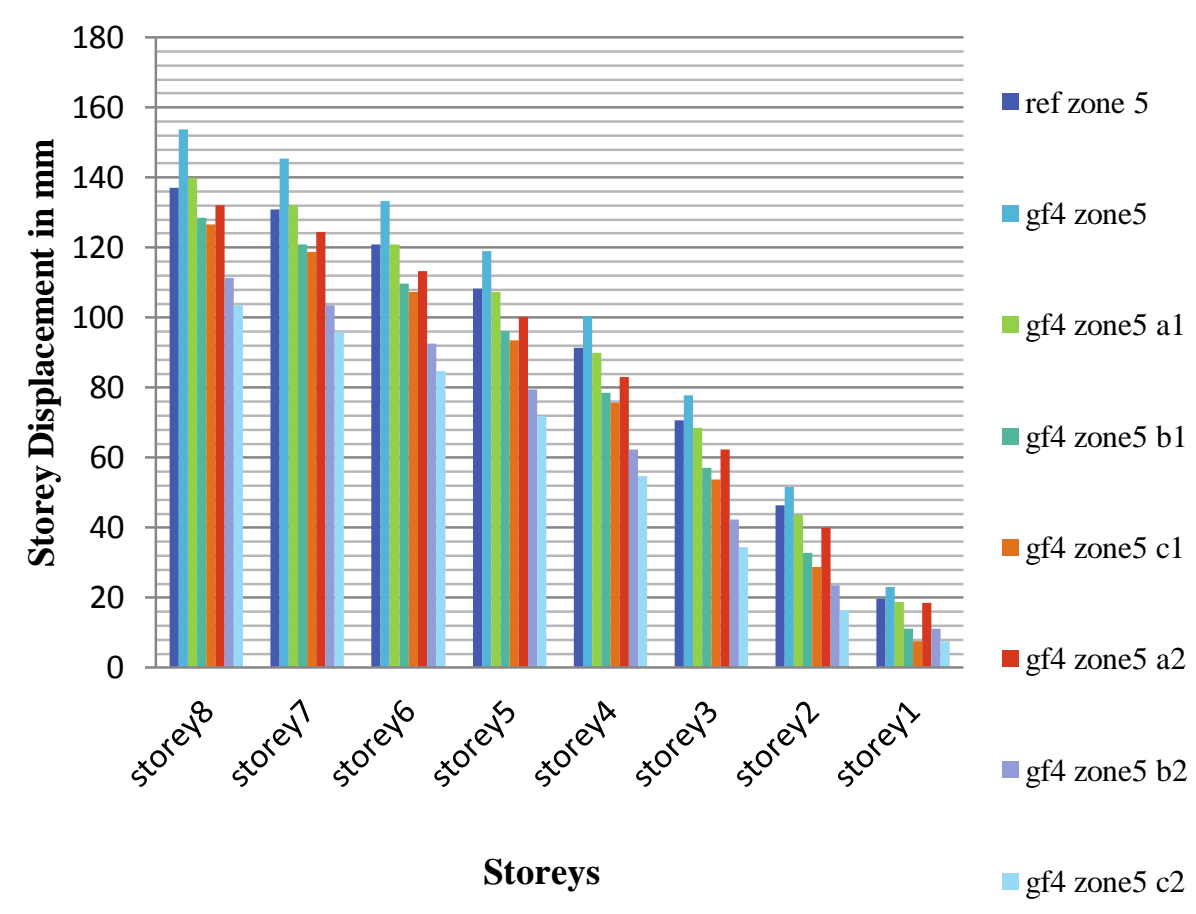

Fig -20: Storey displacement in G+7 irregular building 1

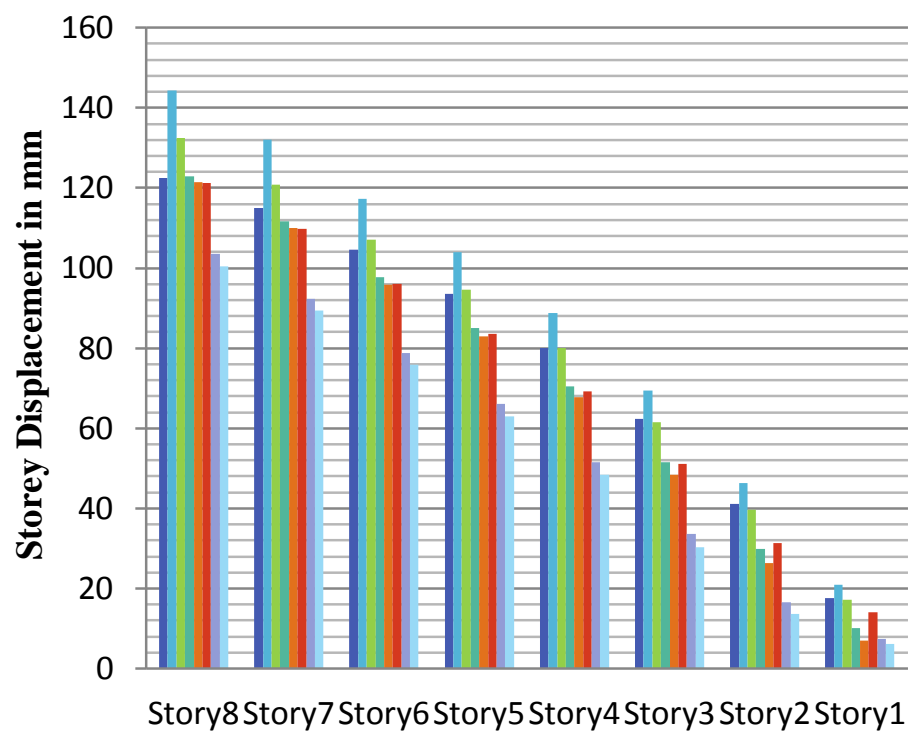

Storeys ref zone5

- gf4 zone5

gf4 zone5 a1

gf4 zone5 b1

- gf4 zone5 c1

- gf4 zone5 a2

af4 zone5 b2

gf4 zone2 c2

Fig -21: Storey displacement in G+7 irregular building 2 


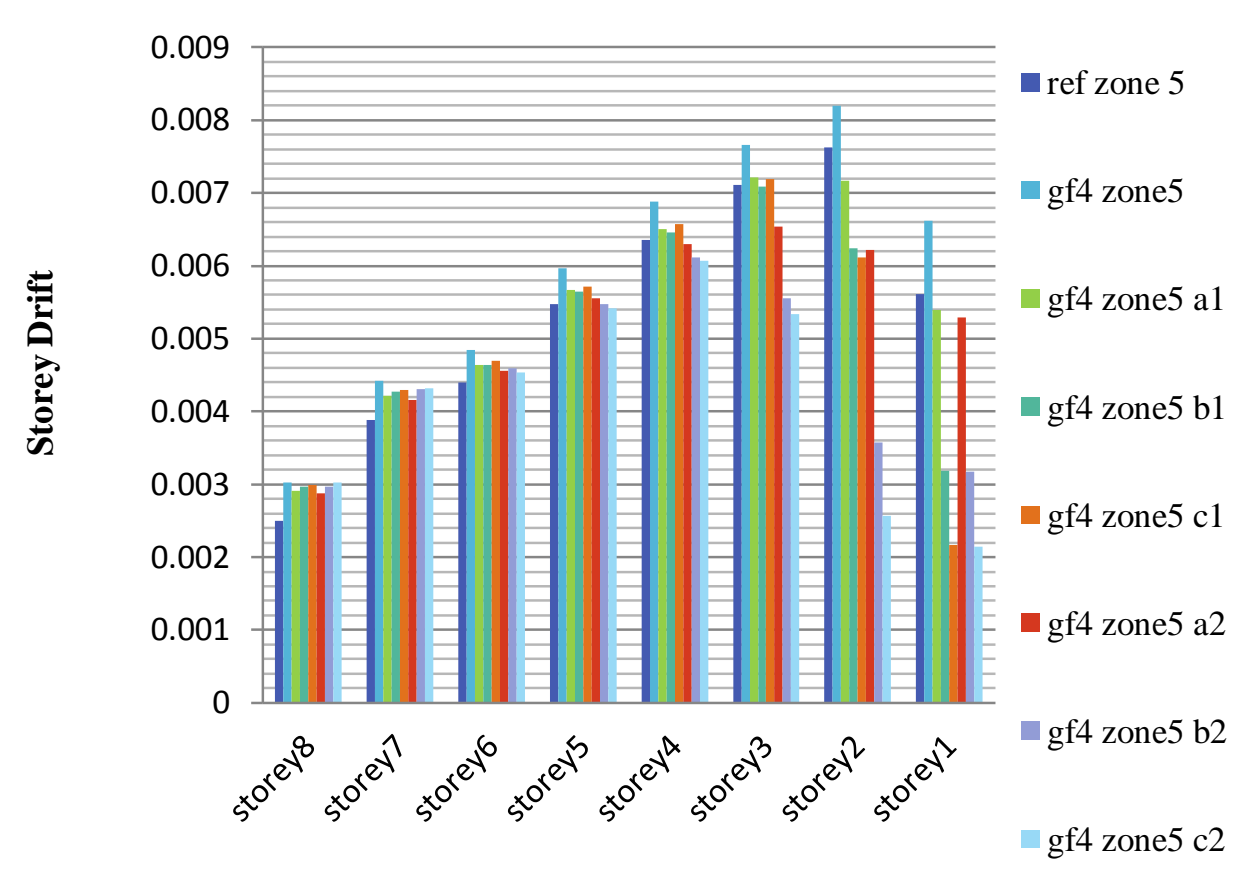

Storeys

Fig -22: Storey drift in G+7 irregular building 1

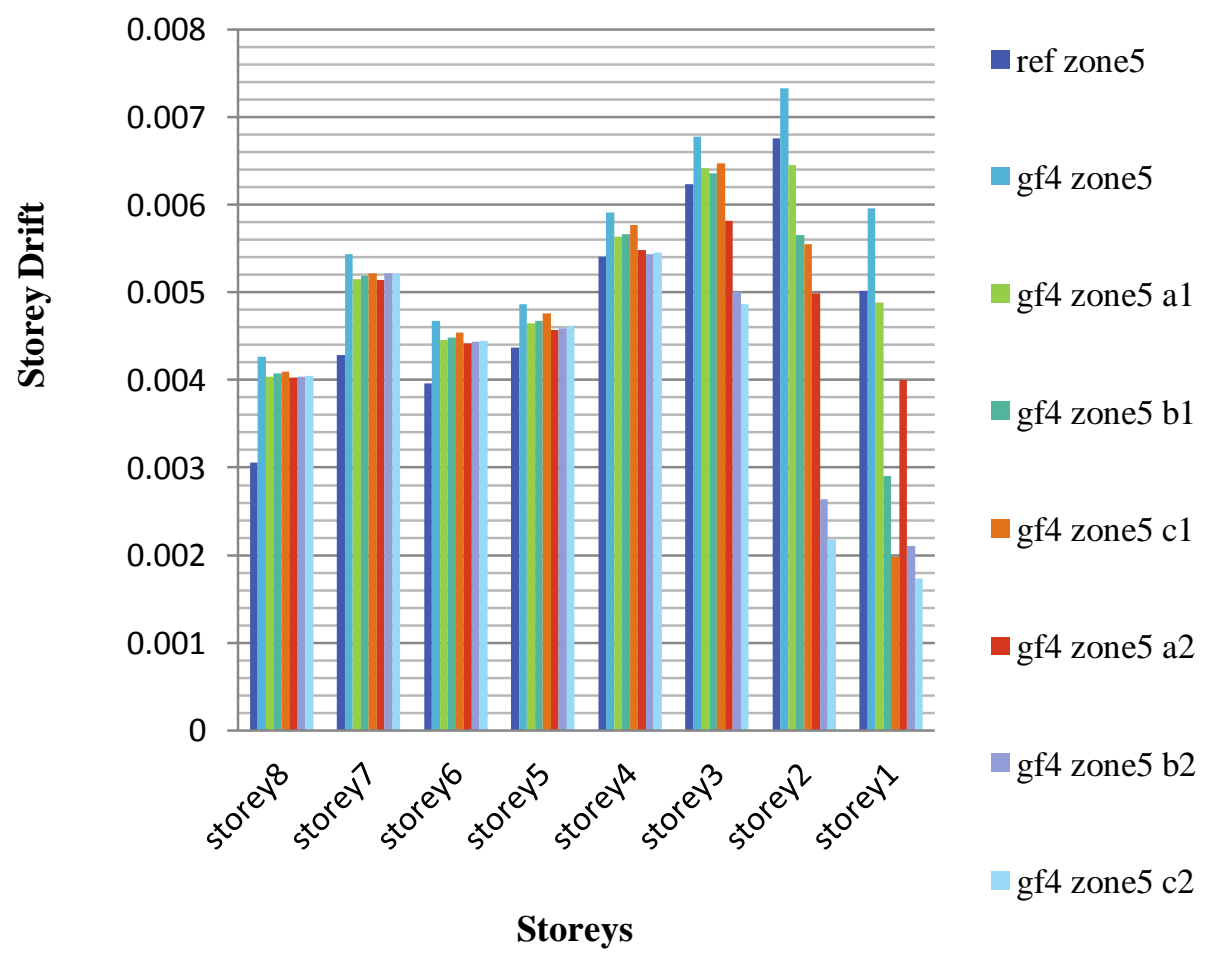

Fig 23: Storey drift in G+7 irregular building 2 


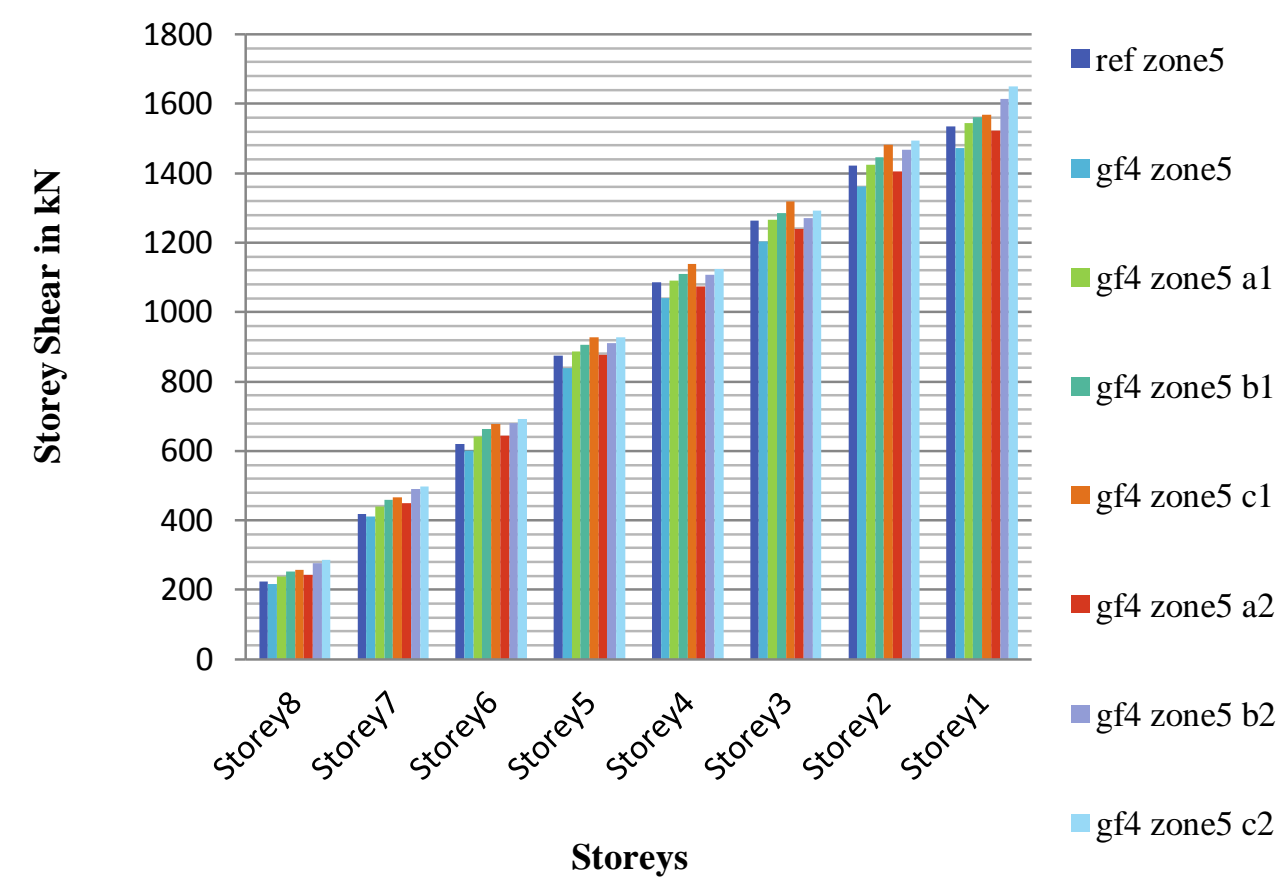

Fig -24: Storey shear in G+7 irregular building 1

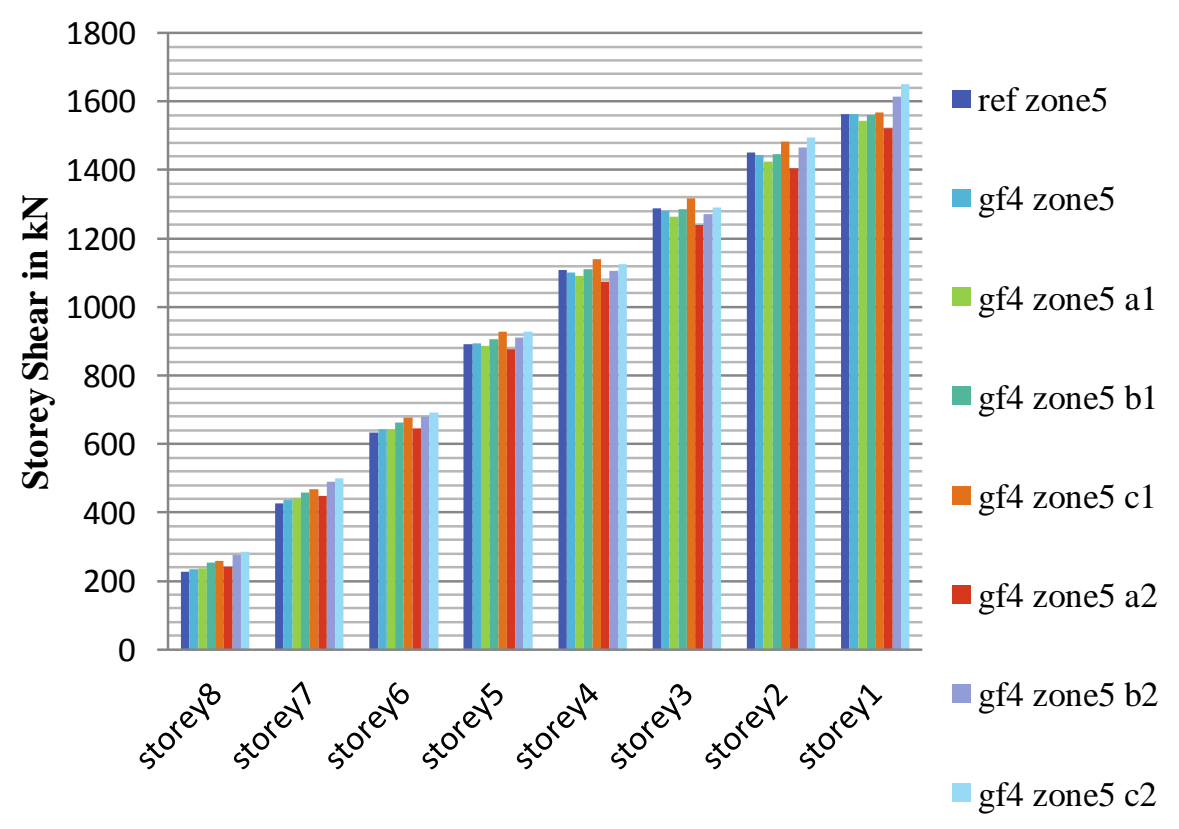

Storeys

Fig -25: Storey shear in G+7 irregular building 2

\section{RESULTS AND DISCUSSION}

\subsection{Storey Displacement}

Storey displacement is maximum for floating column at ground floor position 4 for all model frames as the mass carried by it at position 4 is maximum. Storey displacement in irregular structure type 2 is more than irregular structure type 1 [fig. 8,9,14 \& 15]. With floating column, for lower floors it increases by $18 \%$ for both structures. While for upper floors it increases by $12 \%$ and $18 \%$ respectively for irregular structure 1 and 2. With increase in size of beams and column storey displacement decreases. In first case reduction in displacement of lower floors is very large as compared to upper floors. However in second case (a2, b2, c2) reduction in upper floors are also significant $(14 \%, 28 \%$, $32 \%$ respectively for a2, b2 \& c2) [fig. 20, 21]. 


\subsection{Storey Drift}

Storey drift increases due to presence of floating column. It is maximum at second floor for floating column at ground floor position 4 [fig. 10, 11, $16 \& 17$ ]. Storey drift is more in $\mathrm{G}+7$ than $\mathrm{G}+5$. For case 1 reduction in drift is at first floor and second floor only so that maximum storey drift reduces by $12 \%, 24 \%, 25 \%$ for a1, b1 \& c1 respectively after which it increases up to $6 \%$. This happened because of higher reduction of storey displacement in lower floors than upper floors. For case 2, there is no increase in storey drift for above floors. So the maximum drift is reduced by $24 \%$, $56 \%, 69 \%$ for a2, b2 \& c2 respectively [fig. 22,23 ].

\subsection{Storey Shear}

Storey shear reduces due to presence of floating column in building as the mass is less for building with floating column. It is more for irregular structure 1 [fig. 12, 13, 18 $\&$ 19]. Due to increase in size of beams and columns the mass increases and therefore storey shear increases. It increases by $10 \%, 17 \%, 20 \%$, for a1, b1, c1 respectively and $7 \%, 21 \%, 29 \%$ for a2, b2 and c2 respectively [fig. 24, 25].

\section{CONCLUSION}

Following conclusions have been made on the basis of analysis and results:

i. Floating columns should be avoided in high rise building in zone 5 because of its poor performance.

ii. Storey displacement and storey drift increases due to presence of floating column.

iii. Storey displacement increases with increase in load on floating column.

iv. Storey shear decreases in presence of floating column because of reduction mass of column in structure.

v. Increase in size of beams and columns improve the performance of building with floating column by reducing the values of storey displacement and storey drift.

vi. Increasing dimensions of beams and columns of only one floor does not decreases storey displacement and storey drift in upper floors so dimensions should be increased in two consecutive floors for better performance of building.

\section{REFERENCES}

[1] Banerjee Susanta, Patro S. K., "Estimation of the Park-Ang Damage Index for Floating Column Building with Infill Wall", International Journal of Civil, Architectural, Structural and Construction Engineering, Vol. 08, pp. 760-763, 2014.

[2] Agarwal P., Shrikhande M., Earthquake resistant design of structures, Eastern Economy Edition, 2006

[3] Srikanth.M. K, Yogeendra. R. Holebagilu, " Seismic Response Of Complex Buildings With Floating Column For Zone II And Zone V', International journal of Engineering Research-Online, vol. 02., pp. 01-11, 2014.
[4] Poonam, Kumar Anil, Gupta A.K.," Study of response of structurally irregular building frames to seismic excitations", International Journal of Civil, Structural, Environmental and Infrastructure Engineering Research and Development, Vol.2, pp. 25-31, 2012.

[5] Kara N., Celep Z., "Nonlinear seismic response of structural systems having vertical irregularities due to discontinuities in columns", 15 WCEE, 2012.

[6] Nautiyal Prerna, Akhtar Saleem, Batham Geeta, “ Seismic Response Evaluation of RC frame building with Floating Column considering different Soil Condition, International Journal of Current Engineering and Technology", Vol.4, pp. 132-138, 2014.

[7] Shah B.A., Patodi S.C., "Performance Based Seismic Evaluation of RC Frames with Floating Columns", NBMCW, 2011. 